\title{
Kolekcje chrześcijaństwa w średniowieczu - próba odczytania znaczenia na podstawie wybranych przykładów
}

Tworzenie kolekcji przedmiotów cennych, wyjątkowych, niosących znaczenie należy do istotnego składnika kultury chrześcijańskiej. Zbiory kościelne pełniły szczególną rolę w wiekach średnich. Celem niniejszego przedłożenia jest wykazanie, że średniowieczna kolekcja była traktowana jako wyjątkowe dzieło kultury, które było jednak tworzone w ciągu długiego czasu. Kolekcje powstawały jako rezultat decyzji wspólnot i korporacji i jako takie wyrażały ważkie dla nich treści teologiczne i filozoficzne. Nie zawsze były przeznaczone do odbioru i odczytywania przez szerokie grono osób, zwykle były zarezerwowane dla elit. Jednak doświadczenie kolekcjonowania i wyłączania przedmiotów z codzienności, jakie miało miejsce w przedchrześcijańskiej kulturze ludów germańskich, znalazło kontynuację w chrystianizowanej Europie.

Zadaniem niniejszego artykułu jest również podjęcie próby analiz struktury i zawartości kościelnych kolekcji tej epoki oraz poszukiwanie najlepszych metod tej analizy. Celem analizy jest przede wszystkim

1 Ks. Dariusz TABOR CR, dr hab., historyk sztuki, profesor nadzwyczajny w Instytucie Historii Sztuki i Kultury UPJP II, kierownik Katedry Historii Sztuki Starożytnej i Średniowiecznej. Jego głównymi zainteresowaniami naukowymi są malarstwo książkowe i rękopisy iluminowane, sztuka cystersów, treści sztuki średniowiecznej. E-mail: dariuszcr@interia.pl. 
odczytanie orędzia, przesłania, jakie niesie w sobie kolekcja. Artykuł ma więc pokazać, że takie przesłanie może nieść każda kolekcja. Punktem wyjścia będzie opis skarbów zawarty w poemacie Beowulf, a przedmiotem rozważań i pogłębionych analiz będą trzy rodzaje kolekcji - skarbce liturgiczne i monarchiczne, biblioteki oraz zbiory relikwii. Przypadkami szczególnymi średniowiecznych kolekcji były osobiste zbiory wybitnych postaci ze świata władzy i kultury. Wybrane przykłady kolekcji nie wyczerpują całego ich bogactwa. Jednakże na ich podstawie zostaną przeprowadzone analizy oraz podjęta zostanie próba odczytania ich funkcji i treści.

Problemem był dobór przykładów kolekcji do analizy. Jakimi kryteriami kierowano się przy wyborze? Wzięto pod uwagę te kolekcje, które, choć już nawet nie istnieją, są opatrzone źródłami dokumentującymi ich stan i zasób oraz mają opublikowane opracowania. Wybrano te kolekcje, które wyróżniały się w danym kraju, regionie oraz stanowiły w tym kraju i w określonej epoce istotny element kultury. Jednakże nie zawsze były one badane pod kątem znaczenia, symboliki i orędzia, jakie niosły.

Dawne kolekcjonerstwo ma bogatą literaturę. Wiele pozycji stało się inspiracją i pomocą w przeprowadzanych przez autora badaniach. Nie sposób wymienić wszystkich, tutaj jest miejsce na wzmiankowanie zaledwie niektórych. Andrzej Ryszkiewicz zaprezentował sylwetki polskich kolekcjonerów w swej pracy wydanej po raz pierwszy w roku 1972 . Zygmunt Ważbiński jest autorem syntezy europejskiego kolekcjonerstwa końca wieków średnich i początków czasów nowożytnych ${ }^{3}$. Zdzisław Żygulski junior poświęcił sporo miejsca średniowiecznemu kolekcjonerstwu w swej syntezie muzealnictwa ${ }^{4}$. Wiele nowych danych, również na temat kolekcji średniowiecznych, wnosi monografia polskiego kolekcjonerstwa artystycznego ${ }^{5}$. Wiele prac na ten temat wykazuje bibliografia 100 tomów

2 A. Ryszkiewicz, Zbieracze i obrazy, wyd. 1, Warszawa 1972; A. Ryszkiewicz, Kolekcjonerzy i miłośnicy, wyd. 2, Warszawa 1981, passim.

3 Z. Waźbiński, Muzea i zbiory artystyczne epoki nowożytnej: wiekXVi XVI, t. 1, Toruń 2006, passim.

4 Z. Żygulski jun., Muzea na świecie: wstęp do muzealnictwa, Warszawa 1982, passim.

5 Skarby Rzeczypospolitej: z dziejów kolekcjonerstwa sztuki w Polsce od XIII do końca XVIII wie$k u$, red. D. Folga-Januszewska, A. Rottermund, Olszanica 2003, passim. 
półrocznika „Archiwa Biblioteki i Muzea Kościelne”. Można przytoczyć niektóre pozycje, które będą przydatne w dalszych badaniach nad zbiorami średniowiecznymi ${ }^{7}$. Michał Mencfel przedstawił zjawiska kolekcjonerstwa na Śląsku w czasach nowożytnych .

Wszystkie wymienione prace, choć nie dotyczą bezpośrednio tematu niniejszego przedłożenia, stanowią kontekst badawczy, w który wpisują się przeprowadzane przez autor badania.

\section{Germański prolog}

\section{Niech punktem wyjścia naszych rozważań będzie fragment poema- tu Beowulf:}

A teraz idź, mówi Beowulf, obejrzeć skarb pod szarą skałą, ukochany Wiglafie. Idź teraz, gdy smok leży - śpiący, ciężko zraniony i pozbawiony skarbu. Pośpiesz, abym mógł ocenić starożytne bogactwo i złote dziedzictwo. Dołóż starań, abym dokładnie przyjrzał się błyszczącym klejnotom, tak aby bogactwo skarbu pozwoliło mi łatwiej rozstać się z tym życiem i moim krajem, którym tak długo rządziłem. Następnie usłyszałem, że syn Weohstana, po zakończeniu mowy swego rannego i poszkodowanego $\mathrm{w}$ bitwie pana, prędko posłuchał oraz poniósł swą kolczugę, utkaną zbroję pod sklepienie kurchanu. Gdy młody, odważny tan, wsławiony zwycięstwem, przechodził obok tronu, ujrzał mnóstwo najcenniejszych klejnotów, odbijające blask złoto leżące na ziemi, cudowne przedmioty wiszące na ścianie. Ogarnął jaskinię smoka, starożytnego, skrzydlatego potwora, stojące wazy i misy starożytnych, pozbawione ornamentu i połysku. Było tam mnóstwo żelaznych, zardzewiałych hełmów oraz przemyślnie skręconych bransolet. Czy to skarb, czy złoto pod ziemią, może z łatwością przetrwać każdego z ludzi, tego również, kto je ukrył... ${ }^{9}$

6 A. Hamryszczak, Bibliografia zawartości pótrocznika „Archiwa Biblioteki i Muzea Kościelne”, t. 1-100, „Archiwa, Biblioteki i Muzea Kościelne” [dalej: ABMK], R. 101 (2014), s. 5-91.

7 W. Bielak, Księgozbiór panien Norbertanek w Imbramowicach, ABMK R. 95 (2011), s. 5-10; S. Fedorowicz, Średniowieczne lekcjonarze w zbiorach wawelskich, ABMK R. 89 (2008), s. 195-224; U. Kopeć-Zaborniak, Dzieje księgozbiorów średniowiecznych bibliotek benedyktyńskich, ABMK R. 90 (2008), s. 79-89; T. Stolarczyk, Książka i biblioteka w życiu średniowiecznych i staropolskich konwentów dominikańskich na przykładzie klasztorów środkowopolskich, ABMK R. 100 (2013), s. 341-354.

8 M. Mencfel, Skarby natury i sztuki: prywatne gabinety osobliwości, kolekcje sztuki i naturaliów na Śląsku w wiekach XVII i XVIII, Warszawa 2010, passim.

9 Beowulf: revised edition, edited with an introduction, notes and new prose translation by M. Swanton, Manchester-New York 1997, wersy 2743-2766, s. 164-167, tłum. D. Tabor. 
Fragment ten ujawnia mentalność germańskich ludów, mającą jeszcze metrykę przedchrześcijańską. Skarby zgromadzone w jaskini smoka, ukryte przez ziemię, a teraz zdobyte dzięki odwadze zmagających się z potworami wojowników, świadczą o ich odwadze, determinacji, ale też o pozycji, prestiżu i mocy. Zanim zostały zdobyte, służyły smokowi. Zostały obłożone przekleństwem po to, aby nie zostały rozgrabione. To przekleństwo świadczyło o doniosłości tego skarbu i jego funkcji. Potęga zła, którą wyrażał potwór, była wsparta przez ukryty i przeklęty skarb. Kluczem do zrozumienia istoty skarbu była owa klątwa, nałożona na tego, kto ośmieliłby się naruszyć ów skarb. Wskazuje ona na dwa aspekty owej kolekcji. Pierwszy aspekt to nienaruszalność i nietykalność skarbu. Ma on pozostać w określonym miejscu i żadna z rzeczy należących do niego nie może być zabrana. Drugi aspekt to wyłączne prawo do skarbu, które posiada smok, jego strażnik. U podłoża leży decyzja o wyłączeniu wszystkich tych przedmiotów z powszedniego, zwykłego użytku i włączenie ich do sfery pozaziemskiej.

Analogiczne potraktowanie zespołu przedmiotów obserwujemy w zbiorach dwóch grobów - grobu Childeryka, króla Franków w Tournai, zmarłego w roku 482 i grobu prawdopodobnie Raedwalda, króla Wschodniej Anglii w Sooton Hoo, zmarłego około roku 625. Pierwszy grób zawierał królewski sygnet, sakiewkę ze złotymi i srebrnymi monetami, złotą fibulę, pas ze sprzączką, złotą bransoletę, dwa miecze dekorowane almadynami i emalią komórkową, topór bojowy oraz kryształową kulę ${ }^{10}$. Grób anglosaski, założony w łodzi zakopanej pod tumulusem, zawierał królewski hełm o wysublimowanej formie, zdobione emalią komórkową i plecionką naramienniki, zdobioną plecionką fibulę płaszcza, tarczę z umbem i uchwytem, miecz z elementami emaliowanymi, topór i włócznię, rogi do picia z metalową, ornamentalną oprawą oraz lirę ${ }^{11}$. Przedmioty z obu grobów stały się nośnikami znaczeń, symbolami, które podkreślały królewskość i nadzwyczajną godność pochowanych osób, przewyższającą godność zwykłego śmiertelnika.

Właściwa germańskim ludom zdolność do tworzenia zbiorów i skarbów, do budowania kolekcji znalazła odpowiedź w chrześcijaństwie. Kultura

10 M. Mączyńska, Światło z popiołu: wędrówki ludów w Europie w IV i V wieku, Warszawa 2013, s. $188-191$.

11 L. Webster, Anglo-saxon art: a new history, London 2012, s. 120-122. 
chrześcijańska doceniła zdolność kolekcjonerską ludów, które wchodziły w jej orbitę. Lokalne wspólnoty powoli odkrywały, że tworzenie zbiorów cennych przedmiotów mieści się w misji Kościoła. Idea i struktura zbioru przedmiotów wyłączonych z codziennego użytku została przejęta przez wspólnoty chrześcijan. Nadano jednak zbiorowi nowe funkcje i nowe treści. Dla potrzeb misji Kościoła ukształtowały się trzy podstawowe typy kolekcji. Były nimi skarbiec, biblioteka oraz zbiór relikwii. Przypadkiem szczególnym stały się prywatne zbiory tworzone przez osoby należące do elit władzy i kultury.

\section{Skarb. Atrybut kapłaństwa i królestwa}

Opactwo w Saint-Denis nie zostało ustanowione w miejscu przypadkowym. Było ono miejscem pochówku i kultu św. Dionizego, apostoła Galii. Zaczęło z czasem spełniać doniosłą rolę kulturową w królestwie Franków. W opactwie powstawał symboliczny skarbiec ${ }^{12}$. W jego skład weszły między innymi przedmioty z czasów karolińskich - tron Dagoberta, figurki szachowe z kości słoniowej, patena z serpentynitu i intaglio z popiersiem, wielki krucyfiks z trzema szafirami jako gwoździami Chrystusa ${ }^{13}$. Czasy opata Sugera przyniosły nowe nabytki. Były nimi słynna waza orla, dzban sardoniksowy, dzban z ptakami, kryształowa waza Alienora czy kielich Sugera z sardoniksową czarą ${ }^{14}$. W skarbcu Saint-Denis przechowywano regalia królów Francji. Udokumentowana została obecność tak zwanej korony Karola Wielkiego oraz berła zwanego jego berłem ${ }^{15}$.

Wszystko to jest zapewne tylko fragmentem pierwotnego, o wiele większego zbioru. Jednak to, co pozostało, definiuje ten zbiór jako kolekcję niosącą podwójne znaczenie i podwójną funkcję. Z jednej strony był

12 B. De Montesquiou-Ferenza, D. Gaborit-Chopin, Le trésor de Saint-Denis: documents divers, Paris 1977, passim; Le trésor de Saint-Denis: catalogue de l'exposition au musée du Louvre du 12 mars au 17 juin 1991, Paris 1991, passim.

13 B. De Montesquiou-Ferenza, D. Gaborit-Chopin, Le trésor de Saint-Denis: documents divers, dz.cyt., plansze 16, 36, 39-40, 58-61.

14 Tamże, plansze 23, 24, 26, 27, 42, 47.

15 Tamże, plansze 72, 94. 
to zbiór przedmiotów, które były stosowane do sprawowania liturgii w opactwie. Unaocznia on więc kult liturgiczny wspólnoty mniszej, jego zasięg, kształt, treść oraz splendor. Zbiór ten ujawnia więc treści liturgii i jej rzeczywistość. Z drugiej strony zbiór ten zawierał regalia - berła, korony - traktowane jako przedmioty uświęcone, bo i używane do uświęcania, konsekracji i błogosławieństwa osób sprawujących władzę królewską. Te dwie rzeczywistości współistniały w skarbcu przechowywanym w opactwie św. Dionizego.

Jednym z najbardziej znaczących zbiorów - skarbców był zbiór regaliów Świętego Cesarstwa Rzymskiego. Jego najważniejszym przedmiotem była Reichskrone - ośmioboczna korona, zdobiona szlachetnymi kamieniami, symbolizująca niebieskie Jeruzalem, powstała po roku 960. Zawiera ona cztery emaliowane plakiety z postaciami Dawida, Salomona, Ezechiasza i Chrystusa w otoczeniu aniołów ${ }^{16}$. Był to instrument koronacji cesarzy z dynastii saskiej, lecz jeszcze bardziej narzędzie sakralizacji cesarskości i sankcji religijnej, jaką uzyskiwali cesarze dynastii saskiej. Do tego skarbca należał również krzyż cesarstwa, zdobiony rzędami pereł, święta włócznia, miecz cesarstwa, miecz ceremonialny, jabłko cesarskie, komplet ubiorów ceremonialnych oraz zespół relikwiarzy - relikwiarz z pozostałościami szopy narodzenia, relikwiarz z ogniwami łańcucha, relikwiarz zęba Jana Chrzciciela, relikwiarz ramienia św. Anny, relikwiarz szat św. Jana Ewangelisty ${ }^{17}$. Wszystkie wyżej wymienione klejnoty w latach 1424-1796 przechowywane były w Norymberdze. Istnieje też zespół klejnotów cesarskich, które były przechowywane w Akwizgranie. Obecny kształt tego zbioru jest rezultatem długotrwałego procesu gromadzenia przedmiotów.

Zbiór ten unaoczniał prawną jedność i tożsamość cesarstwa oraz potwierdzał jego podmiotowość. Jednakże jego znaczenie wykraczało

16 L. Castelfranchi Vegas, Arte ottoniana intorno al anno mille, Milano 202, s. 51-53; H. M. Schaller, Die wiener Reichskrone - enstanden unter König Konrad III, [w:] Die Reichskleinodien. Herschaftszeichen des Heiligen Römischen Reiches, Göppingen 1997, s. 58-105.

17 H. Filitz, Die Schatzkammer in Wien: Symbole abendländischen Kaisertums, Wien, 1986, passim; H. Trnek, Die Insignien des Heiligen Römischen Reiches, [w:] Die Reichskleinodien..., dz.cyt., s. 10-29; Ch. Lannert, Die Reichskleinodien: Bedeutung, Symbolik und Gebrauch der Herschaftszeichen des Alten Reiches, München 2013, passim. 
poza definicje prawne. Przedmioty tego zbioru, w większości używane w liturgii koronacji, niosły w sobie treści uświęcenia urzędu cesarskiego i konsekracji osoby koronowanej. Określały one charakter władcy, który od momentu koronacji był postrzegany jako osoba sakralna obdarzona szcególną konsekracją ${ }^{18}$.

Skarb królewski był również obecny w polskiej kulturze politycznej i symbolicznej. Był on kształtowany od restytucji Królestwa Polskiego w 1320 roku, a pierwszą średniowieczną inwentaryzację uzyskał w roku $1475^{19}$. Inwentarz ten, opracowany przez Michała Myślińskiego, dokumentuje szczegółowo zawartość skarbca, lecz pokazuje jednocześnie preferencje kolekcjonerskie, a nawet daje świadectwo, jak ceniono pewne przedmioty i jakie znaczenie im nadawano ${ }^{20}$. Feliks Kopera już w 1904 roku opracował dzieje polskich regaliów ${ }^{21}$. Najważniejszą częścią skarbca są regalia, czyli przedmioty używane do koronacji królewskich. Należały do nich: korona używana do koronacji, dwie korony homagialne, taca do złożenia korony w czasie koronacji, srebrne berło i dwa jabłka, jabłko z krzyżem oraz Biblia koronacyjna. Niewielką, choć istotną częścią były pamiątki osób i wydarzeń - szczerbiec (item Gladius Scyrbecz), dwa miecze grunwaldzkie (item duo Gladij a Magistro Cruciferorum), opończa Jadwigi Andegaweńskiej (item tectura alias Opona flavei coloris cum Margarittis olim Dominae Hedwigis Reginae). Liczną grupę stanowią przedmioty religijne, wśród których wyróżnia się zbiór relikwii (reliquiae in una bursa, cisticula parva cum diversis reliquijs, item Reliqiae in cristallo dispositae cum argento deaurato, de tunica Domini parva Particula, caput sanctae Margarethae in argento deaurato altae dispositionis i inne). Interesujący jest zbiór przedmiotów religijnych obrządku bizantyńskiego (quatuor pectoralia fidei Graecae deposita argento deaurato, unum pectorale de fidei Graeca, Cisticula deauratae Graece in qua continentur imagi-

18 L. Castelfranchi Vegas, Arte ottoniana..., dz. cyt., s. 53.

19 Acta tesauri Regni Poloniae saeculi XVII (Kraków, Biblioteka Czartoryskich, rkps III 1080), s. 456-458; M. Myśliński, Klejnoty Rzeczypospolitej: zawartość skarbca koronnego na Wawelu w świetle jego inwentarzy z lat 1475-1792, Warszawa 2007, passim.

20 M. Myśliński, Klejnoty Rzeczypospolitej..., dz. cyt., passim.

21 F. Kopera, Dzieje skarbca koronnego czyli insygniów i klejnotów koronnych polskich, Kraków 1904, passim. 
nes Beatae Virginis et Angelorum, Crux dispositionis graecae in saeculo nigro). Obszerny i bogaty jest zbiór kamieni szlachetnych i osobliwości (cristallus disposita cum argento et cathena aurea, lapis in cordula viridea, lapis Longus Cristallinus cum argento dispositus, cochlear de lapide jaspidis cum argento, lapis serpentinus in argento deaurato in Zona rubea et Flavea, in pulla parva cochlear argenteum et Lapis corralis Magnus, in Almaria Credentiale cum Lignis Draconum et Coralis). W skład zbioru wchodziło również kilka obrazów (tabula parva cum craticula, due tabulae fidei graecae, Imagines de Lapidibus, imagines alias tabulae ligneae) oraz dokumentów.

Królewska kolekcja krakowska był więc zbiorem przedmiotów o wielkiej różnorodności i zróżnicowanej funkcji. Każdy z rodzajów przedmiotów był jednak podporządkowany funkcji wyrażenia dwóch naczelnych idei króla jako osoby sakralnej i konsekrowanej oraz królestwa, które jest rzeczywistością trwałą i ma swe źródła w nadprzyrodzoności. Najważniejszą częścią kolekcji był oczywiście zestaw regaliów jako liturgicznych narzędzi konsekracji - namaszczenia i koronacji, jednak pozostałe kategorie przedmioty religijne, kamienie szlachetne, precjoza i osobliwości, a także obrazy i dokumenty służyły podkreśleniu i uwydatnieniu splendoru króla i królestwa jako rzeczywistości nadprzyrodzonych.

Nawet pobieżny przegląd zawartości trzech skarbców pozwala skonstatować, że tego typu kolekcje ujawniają wewnętrzny związek dwóch rzeczywistości średniowiecznej kultury - sacerdotium i regnum, czyli obszaru posługi nauczającej i sakramentalnej Kościoła i obszaru rządzenia państwem. Sprawowanie władzy państwowej było pojmowane jako wykonywanie charyzmatu mającego źródło w rzeczywistości nadprzyrodzonej. Należy podkreślić tutaj wagę liturgii koronacyjnej, w której precjoza królewskie były niezbędnymi instrumentami. Rytuał koronacji opisał Witold Sawicki i przeanalizował go jako źródło państwowości² ${ }^{22}$ Eric Palazzo w swym studium o społecznej roli liturgii podkreślił doniosłość aktu koronacji w sakralizacji władzy ${ }^{23}$.

22 W. Sawicki, Rytuał sakry - koronacji jako źródło prawa i ustroju państw średniowiecznej Europy „Archiwa Biblioteki i Muzea Kościelne” R. 24 (1972), s. 279-293.

${ }_{23}$ E. Palazzo, Liturgie et Société au Moyen Âge, Paris 2000, s. 202-212. 


\section{Biblioteka: obraz świata - naturalnego i duchowego}

Wiele ważkich konstatacji może przynieść analiza zawartości średniowiecznych bibliotek. Jedną z najcenniejszych bibliotek świata zachodniego była biblioteka opactwa cystersów w Cîteaux. Ta pramacierz wszystkich opactw cystersów kształtowała model życia nowych wspólnot oraz proponowała wzorzec powrotu do pierwotnego sposobu praktykowania reguły św. Benedykta. Książka rękopiśmienna była wtedy niezbędnym narzędziem życia wewnętrznego, dlatego znaczenie biblioteki w każdym cysterskim opactwie trudno przecenić. Liczba zachowanych woluminów biblioteki Cîteaux może wiele powiedzieć o jej stanie. Otóż z wieku XI zachowały się cztery woluminy, stulecie XII pozostawiło ich 105, a wiek XIII przyniósł 85 kodeksów. Zachowało się również 25 kodeksów XIV-wiecznych oraz 25 rękopisów z XV wieku ${ }^{24}$. Tak więc wiek XII okazał się pod względem duchowym i kulturalnym wiekiem rozkwitu, a czas rządów opata Stefana Hardinga (1108/9-1123) był czasem, w którym powstało wiele znakomitych woluminów ${ }^{25}$. Najważniejszym kodeksem była wielotomowa Biblia Stefana Hardinga (Dijon, Bibliothèque Municipale, Mss 12-13, 14-15) ${ }^{26}$. Doniosłą grupę stanowiły starannie przepisywane i iluminowane dzieła ojców Kościoła ${ }^{27}$. Preferowano komentarze do ksiąg Starego i Nowego Testamentu. W bibliotece Cistercium znalazły się więc teksty św. Augustyna - Enarrationes in psalmos (Dijon, Bibliothèque Municipale, 144, 145, 146, 147), De civitate Dei (Dijon, Bibliothèque Municipale, 158), De Trinitate (Dijon, Bibliothèque Municipale, 141), Epistolae (Dijon, Bibliothèque Municipale, 157), De doctrina Christiana (Dijon, Bibliothèque Municipale, 45), Quaestionesin Heptateuchum (Dijon, Bibliothèque Municipale, 138), Casiodora-Expositio psalmorum (Dijon, Bibliothèque Municipale, 56), Grzegorza Wielkiego - Moralia in Iob, pars I i II (Dijon, Bibliothèque Municipale, 168-169, 170, 173), Epistolae (Dijon, Bibliothèque Municipale, 180), Euzebiusza z Cezarei - Historia Ecclesiastica (Dijon, Bibliothèque Municipale, 572), Hieronima - Epistolae et sermons

24 Y. Zaluska, L'enluminure et le scriptorium de Cîteuax au XIIe siècle, Cîteaux 1989, s. 15-36.

25 J. de la Croix Bouton, Stephan Harding, [w:] Lexikon des Mittelalters, t. 18, StuttgartWeimar 1999, kol. 119-120.

26 Y. Załuska, Manuscrits enluminés de Dijon, Paris 1991, s. 49-56.

27 Y. Załuska, Manuscrits enluminés de Dijon, dz.cyt. s. 49-56. 
(Dijon, Bibliothèque Municipale, 155), Commentarii in Danielem, In prophetas minores, Commentarii in Ecclesiastem (Dijon, Bibliothèque Municipale, 132), Commentarii in Isaiam (Dijon, Bibliothèque Municipale, 129) Commentarii in Ezechielem (Dijon, Bibliothèque Municipale, 131) Breviarium in psalmos (Dijon, Bibliothèque Municipale, 37) Commentarius in Evangelium secundum Marcum (Dijon, Bibliothèque Municipale, 83). Zaopatrzono również bibliotekę $\mathrm{w}$ dzieła Bedy Czcigodnego - De tabernaculo (Dijon, Bibliothèque Municipale, 41), De templo salomonis (Dijon, Bibliothèque Municipale, 68) Expositio in Evangelii Lucae (Dijon, Bibliothèque Municipale, 77), Paschazego Radberta - Expositio in Lamentationes Jeremiae (Dijon, Bibliothèque Municipale, 68) i Rabana Maura - Commentarii in Deuteronomium (Dijon, Bibliothèque Municipale, 54), Commentarii in Ecclesiasticum (Dijon, Bibliothèque Municipale, 66) Commentarii in Numeros (Dijon, Bibliothèque Municipale, 53). Nie zabrakło rownież dzieł św. Bernarda z Clairvaux - Vita Sanctae malachiae, Homiliae „super missus est” (Dijon, Bibliothèque Municipale, 658), Sermones in Cantica canticorum (186), Epistoles et Liber de diligendo Deo (Dijon, Bibliothèque Municipale, 189) oraz autorów mu współczesnych: Hugona de sancto Victore - De arca Noe (Dijon, Bibliothèque Municipale, 39), Ricardusa de sancto Victore - Beniamin minor (Dijon, Bibliothèque Municipale, 39) i Opuscula (Dijon, Bibliothèque Municipale, 42).

Ten pobieżny przegląd treści dzieł pozwala na sformułowanie pewnego ważnego wniosku. Zawartość biblioteki wykazuje, że życie intelektualne i duchowe wspólnoty Cîteaux koncentrowało się na lekturze i rozważaniu Biblii, na jej interpretowaniu i komentowaniu. Dla mnichów cysterskich Biblia była źródłem i inspiratorem życia duchowego oraz źródłem światła na życie poświęcone Bogu w klasztorze. Ojcowie Kościoła byli natomiast dla nich mistrzami w jej interpretacji.

Biblioteka katedry wawelskiej istniała już zapewne od początku XI stulecia, jednak dopiero na początku XII wieku doczekała się katalogu. Został on sporządzony na pustej karcie kodeksu zwanego Collectio trium partium (Kraków, Biblioteka Kapitulna, nr 84) w roku $1110^{28}$. Na

28 A. Vetulani, Krakowska biblioteka katedralnaw świetle swego inwentarza z roku 1110, ,Slavia Antiqua" R. 4 (1953/54), s. 163-192; M. Plezia, Księgozbiór katedry krakowskiej wedle inwentarza z roku 1110, [w:] Silva Rerum, Kraków 1981, s. 16-29. 
podstawie jego zapisów wiemy, że w zbiorach tej książnicy znajdował się zespół dzieł starożytnych - historyka Salustiusza, komediopisarza Terencjusza, satyryka Persjusza oraz poetów Owidiusza i Stacjusza, a także zestaw starożytnych podręczników gramatyki, retoryki i dialektyki. Kolejnym sektorem zbioru były dzieła starożytnego i średniowiecznego chrześcijaństwa - Etymologie Izydora z Sewilli, pisma Boecjusza, cztery psałterze, trzy kodeksy Biblii, dzieła Grzegorza Wielkiego, dwa zbiory homilii ojców Kościoła. Nie zabrakło w księgozbiorze wszystkich podstawowych ksiąg liturgicznych.

Analiza powyższego zbioru pozwala dostrzec jego pragmatyczność. Został on stworzony dla celów nauczania w szkole katedralnej. Narzędzia do nauczania trivium zostały w sposób szczególny wyodrębnione. Księgozbiór odpowiadał też na potrzeby codzienne lokalnego Kościoła w zakresie liturgii. Oprócz tego widoczny jest bogaty zestaw tekstów lectio divina. Jednakże pragmatyka nie wyczerpuje wszystkich funkcji biblioteki. Księgozbiór ten integruje w sobie dwie wielkie formacje kulturowe - starożytność klasyczną (dzieła pisarzy i podręczniki) oraz antyk chrześcijański (dzieła ojców Kościoła), łącząc je ze współczesnym życiem liturgicznym wczesnośredniowiecznego Kościoła lokalnego (księgi liturgiczne). Odkrywa w ten sposób umysłowość i duchowość tworzących go ludzi, którzy wykształcenie w duchu antycznym łączyli z duchową formacją biblijną i patrystyczną oraz liturgią. Ukształtowana przez nich kolekcja ksiąg jest obrazem swoistego uniwersum kulturowego. To uniwersum składało się z trzech warstw - pogańskiej, patrystycznej oraz wczesnośredniowiecznej. Taka wizja była właściwa kulturze mniszej.

Bibliotekami, które wykazują typowe cechy biblioteki mniszej, były cysterskie biblioteki w Lubiążu i Rudach. Konstanty Klemens Jażdżewski na podstawie średniowiecznych not własnościowych zidentyfikował 10 kodeksów z biblioteki lubiąskiej ${ }^{29}$. Stwierdził również, że około roku 1430 mogło się tam znajdować około 900 woluminów ${ }^{30}$. Stanisław Rybandt zidentyfikował 342 kodeksy średniowieczne z biblioteki rudz-

29 K. K. Jażdżewski, Lubiąż: losy i kultura umysłowa śląskiego opactwa cystersów (1163-1642), Wrocław 1993, s. 139.

30 K. K. Jażdżewski, Lubiąz: losy i kultura umysłowa..., dz. cyt., s. 142-143. 
kiej $^{31}$. Należały do nich znakomite kodeksy, a wśród nich Moralia in Iob św. Grzegorza Wielkiego z roku 1391 (Wrocław, Biblioteka Uniwersytecka, IF 149) czy Biblia z roku 1285 (Wrocław, Biblioteka Uniwersytecka, IF 5). Na karcie 1r tego ostatniego kodeksu znajduje sie zwięzły katalog biblioteki klasztornej ${ }^{32}$. Cysterskie biblioteki gromadziły teksty Biblii, dzieła patrystyczne, księgi liturgiczne. Wynikało to ze skoncentrowania życia mniszego na lectio divina i liturgii.

Odmienny typ reprezentował zbiór ksiąg wrocławskiego konwentu dominikanów. Pod koniec XV wieku mógł on liczyć nawet od 300 do 400 woluminów $^{33}$. Najcenniejszą częścią tego księgozbioru były dzieła średniowiecznych teologów - Mikołaja z Liry, Wilhelma Durandusa, Henryka Harforda i innych. Dumą biblioteki było Quattuor libri sententiarum Piotra Lombarda oraz Summa theologica Tomasza z Akwinu. Fragmenty katalogu biblioteki, sporządzanego w latach 1451-1476, wprowadziły podział całego zbioru na kategorie ${ }^{34}$.

Biblioteka dominikańska wniosła nową jakość. Była bowiem biblioteką służącą do nauczania. Nie było to nauczanie typu mniszego, lecz dydaktyka przygotowująca do podjęcia studiów universyteckich, a nawet zbliżona do uniwersyteckiej. Każda z prowincji dążyła do tego, aby stworzyć u siebie studium generale, w którym nauczano trivium, quadrivium, lecz również teologii ${ }^{35}$. Nawet jeśli dany klasztor nie prowadził regularnego studium, codzienna formacja zakonników zawierała jego elementy i zmierzała w kierunku solidnej formacji intelektualnej. Nauczanie to zakładało prowadzenie krytycznych badań nad tekstami, których wyniki upubliczniano w postaci komentarza. Dlatego potrzebne były nowe księgi. Oprócz tego dominikanie potrzebowali ksiąg, które służyły im pomocą w wysublimowanym kaznodziejstwie. Pragmatyzm kolekcjonerski,

\footnotetext{
31 S. Rybandt, Średniowieczne opactwo cystersów w Rudach, Wrocław 1971, s. 130.

32 S. Rybandt, Średniowieczne opactwo cystersów w Rudach, dz.cyt., s. 188.

33 K. Zawadzka, Biblioteka klasztoru dominikanów we Wrocławiu (1226-1810), [w:] Studia nad dziejami dominikanów w Polsce 1222-1972, t. 2, red. J. Kłoczowski, Warszawa 1975, s. 307-308.

34 K. Zawadzka, Biblioteka klasztoru dominikanów..., dz.cyt., s. 305, 309; A Świerk, Fragmenty piętnastowiecznego katalogu biblioteki wrocławskich dominikanów, „Sobótka” 21 (1966), s. 550-

35 J. Verger, L'exégèse de l'Université, [w:] Le Moyen Âge et la Bible, sous la direction de P. Riché et G. Lobrichon, Paris 1984, s. 200.
} 551. 
czyli podporządkowanie gromadzenia komentowaniu, nauczaniu i kaznodziejstwu, nie przysłaniał zasadniczego znaczenia kolekcji. Służyła ona bowiem komunikacji, przekazywaniu tego, co zostało odkryte w procesie krytycznej kontemplacji. Dewiza contemplata aliis tradere znajdowała w bibliotece dominikańskiej najpełniejszy wyraz.

Księgozbiór średniowieczny jest wyjątkowym zbiorem, ponieważ w nim ujawniają się wartości i zasadnicze dążenia umysłowości i duchowości ludzi epoki, w której powstał. Jest on obrazem universum duchowego i umysłowego, które było budowane na bazie pragmatycznego księgozbioru. Jest to universum, w którym człowiek średniowiecza doświadcza zarówno wartości kultury, którą zastał (antyk klasyczny, późny antyk chrześcijański) i na bazie tej kultury próbuje budować swoje odniesienie do świata, człowieka i Boga. Podejmuje jednocześnie wysiłek integrowania tych trzech rzeczywistości wokół najwyższej wartości, do której się odnosi - do Boga, z którym buduje więź przez Biblię, ojców Kościoła, teologów i liturgię.

\section{Relikwie - skarb Kościoła pielgrzymującego i zbawionego}

Obecność relikwii jest czymś oczywistym w praktyce wspólnot religijnych i w kulturze religijnej średniowiecza. Wokół relikwii wszak męczennika czy wyznawcy koncentrują się kult, ruch pielgrzymkowy i aktywność artystyczna. Jednakże w niniejszym studium chodzi nie o relikwie indywidualnego patrona, lecz o zbiory relikwii. Takie zbiory bywały częścią innych zbiorów, jakimi są choćby skarbce. Przykładem jest przeanalizowany skarbiec Saint Denis. Jednakże obecne rozważania koncentrują się zbiorze relikwii jako samoistnym tworze kulturowym.

Zbiór relikwii unaocznia szafa relikwiarzowa z opackiego kościoła cysterskiego w Doberanie, powstała w 2. połowie XIII wieku ${ }^{36}$. Jest to prostopadłościenna, zamykana jednoskrzydłowymi drzwiami szafa, której wnętrze podzielono na pięć poziomów, z których każdy mieści po trzy

36 A. Lener, Reliquien in Kunst und Kult zwischen Antike und Aufklärung, Darmstadt 1995, s. $178-180$. 
wnęki, ujęte ostrołukowymi arkadkami na kolumienkach. Każda z wnęk przygotowana była do przyjęcia relikwii świętego patrona, czczonego w opactwie. Istnieje opinia, że szafa ta, wypełniona relikwiarzami, mogła stanowić rodzaj nastawy głównego ołtarza.

W pewnym sensie jest do niej zbliżona skrzynia relikwiarzowa z XIII wie$\mathrm{ku}$, również pierwotnie ustawiona na mensie ołtarza, pochodząca z opackiego kościoła cysterskiego w Loccum ${ }^{37}$. Pierwotnie miała ona kształt prostopadłościennej szafy nakrytej dachem dwuspadowym. Jej ścianka przednia przepruta była szeregiem wnęk, przeznaczonych do umieszczenia relikwiarzy.

Około roku 1310 pierwotną szafę relikwiarzową ołtarza w Doberanie zastąpiło trójskrzydłowe retabulum ${ }^{38}$. Skrzydła boczne zaopatrzone były w trzy rejestry ostrołukowych wnęk, mieszczących figurki świętych. Kwaterę środkową stanowiło siedem wysokich, ostrołukowych arkad, zwieńczonych wimpergami. Środkowa arkada była prześwitowa na całej wysokości. Arkady boczne, po trzy z każdej strony, były podzielone na dwa rejestry - dolny i górny. Powstały w ten sposób wnęki, które były gotowe do przyjęcia relikwii.

Około 1360 roku pojawiają się dwa dzieła, które zostają stworzone po to, aby chronić i ukazywać mnogość relikwii. Retabulum ołtarza w cysterskim kościele w Marienstatt oraz tak zwany ołtarz św. Klary, czyli retabulum głównego ołtarza kościoła klarysek pod wezwaniem św. Klary w Kolonii mają bardzo zbliżoną strukturę $e^{39}$. Są to trójskrzydłowe nastawy, których zarówno kwatera środkowa, jak i skrzydła podzielone są na dwa rejestry, wypełnione arkadowymi i wimpergowymi wnękami. We wnękach górnego rejestru umieszczone są posążki świętych, natomiast we wnękach rejestru dolnego umieszczono relikwiarze hermowe. Te dwie nastawy realizują w pełni ideę retabulum, służącego do umieszczenia i ukazania relikwii.

Istniały też udokumentowane źródłowo kolekcje relikwii na ziemiach polskich. Obszerną monografię poświęciła obecności i stosowaniu relikwii

37 A. Lener, Reliquien in Kunst..., dz. cyt., s. 177-178.

38 A. Lener, Reliquien in Kunst..., dz. cyt., s. 178-180.

39 A. Lener, Reliquien in Kunst..., dz. cyt., s. 180-183. 
Maria Starnawska ${ }^{40}$. Jednym z najważniejszych zbiorów relikwii w Królestwie Polskim był zbiór wawelski. Relacjonujący jego stan Jan Długosz wymienił partykułę krzyża świętego, palec św. Filipa Apostoła, ciała męczenników św. Floriana i św. Stanisława, szczekę św. Jana Chrzciciela, relikwie z głowy św. Wawrzyńca, ząb św. Pawła Apostoła, ramiona św. Bartłomieja, Stefana, św. Tomasza Kantuaryjskiego, św. Briciusa, relikwie św. Innocentego, św. Krzysztofa, św. Witalisa, św. Maurycego, św. Korduli ${ }^{41}$.

Znana była kolekcja relikwii we władaniu najpierw templariuszy, a potem joannitów w Oleśnicy Małej na Dolnym śląsku. W jej skład wchodziły: partykuła Krzyża świętego, relikwie ramienia św. Bartłomieja oraz ramienia św. Tomasza, przechowywane w szkatułkach relikwie św. Piotra, św. Wacława, św. Stanisław, św. Wojciecha, św. Florencjusza, św. Katarzyny, św. Barbary, św. Doroty, św. Apolonii. Do kolekcji należały również zęby św. Krzysztofa, cząstki św. Antoniego, św. Anny i św. Urszuli42

Oczywiście tych kilka przykładów szaf i nastaw oraz zbiorów przeznaczonych do umieszczenia relikwii, a także ich kolekcji gromadzonych w różnych miejscach, nie wyczerpuje różnorodności rozwiązań służących przechowywaniu zbiorów relikwii wielu świętych. Funkcją krypty podchórowej - zarówno pod chórem wschodnim, jak i zachodnim kościołów epoki ottońskiej oraz świątyń romańskich - było przechowywanie relikwii. Ramy z relikwiarzami były również rozpowszechnionym sposobem prezentacji szczątków świętych patronów.

Wydawać by się mogło, że podstawową funkcją XIII- i XIV- wiecznej szafy relikwiarzowej i relikwiarzowego retabulum jest ukazywanie oczom wiernych relikwii, czyli ostensio reliquiarum. Jednakże po przeanalizowaniu przykładów i praktyki ich użycia okazuje się, że aspekt ten nie jest zasadniczy ani konstytutywny dla tego rodzaju struktury, bowiem istniały zbiory relikwii, których nie ukazywano lub ukazywano w wyjątkowych okazjach. Ekspozycje stosowano przecież również w przy-

40 M. Starnawska, Świętych życie po życiu: relikwie w kulturze religijnej na ziemiach polskich $w$ średniowieczu, Warszawa 2008, passim.

${ }_{41}$ Długosz J., Liber beneficiorum dioecesis Cracoviensis, t. 1, Cracoviae 1863, s. 3-4.

${ }_{42}$ M. Starnawska, Świętych życie po życiu..., dz. cyt., s. 138-139; M. Starnawska, Krucjata i Ziemia Świętaw duchowości zakonów krzyżowych w Polsce średniowiecznej, „Saeculum Christianum” 3 (1996) nr 1, s. 173. 
padku relikwii jednej osoby. Wymienione zespoły, zbiory relikwii, zwykle w relikwiarzach różnych form, stanowią nową jakość i oddziaływają przede wszystkim swoją mnogością, wielością oraz zgromadzeniem szczątków osób świętych w jednym miejscu, w stosownych oprawach i w bezpośredniej bliskości. Wyjątkowym tworem kulturowym oddziaływującym estetycznie i religijnie ze szczególną siłą, nawet w przypadku braku ostensio, jest „kolekcja” relikwii wielu świętych, zwykle otaczanych kultem w mieście, opactwie, diecezji czy regionie. Określenie „kolekcja relikwii” może budzić konsternację, a nawet szokować, jednakże ze względu na strukturę i funkcje tego zbioru ta nazwa, zastosowana już uprzednio w niniejszym tekście w stosunku do dwóch rodzajów zbiorów, wydaje się jak najbardziej uprawniona.

Jaką więc funkcję pełniła „kolekcja relikwii”? Była ona uobecnieniem istnienia wielu osób historycznych, które zostały uznane przez Kościół za zbawione, czyli święte. Zebranie ich razem, nawet ukazanie, miało za zadanie potwierdzenie ich istnienia oraz ich życzliwej postawy w stosunku do osób żyjących, w relacji do społeczności królestwa, krainy, diecezji, miasta, opactwa, parafii. Zebrane relikwie świętych miały unaocznić znaną z Credo rzeczywistość communicatio sanctorum. Nasuwa się jednak pytanie: czy jedyną relacją owych świętych uobecnionych przez zbiór relikwii do osób żyjących był patronat i wstawiennictwo? Wydaje się, że nie, choć był on ważny i pożądany. Kult patrona bowiem był czynnikiem konstytuującym wspólnotę, nie tylko kościelną, ale i miejską czy państwową ${ }^{43}$. Jako przykład można by przytoczyć choćby rolę relikwii św. Wojciecha w Gnieźnie czy relikwii św. Krzyża na Świętym Krzyżu ${ }^{44}$. Poza tym relikwie stanowiły czynnik uświęcający przestrzeń i wprowadzający miejsce w system geografii sakralnej ${ }^{45}$. Mnogość relikwii świętych dawała świadectwo prestiżu, znaczenia, ważności, dawności, rangi, dziedzictwa duchowego instytucji. Dlatego też dążeniem wspólnot zakonnych, kapituł, biskupów było sprowadzenie jak największej ilości relikwii, przede wszystkim szczątków męczenników z Rzymu. To dążenie legło u podstaw bardzo wielu kolekcji relikwii.

${ }_{43}$ M. Starnawska, Świętych życie po życiu..., dz. cyt., s. 516-545.

44 M. Starnawska, Świętych życie po życiu..., dz. cyt., s. 528-529.

45 M. Starnawska, Świętych życie po życiu..., dz.cyt., s. 519-526. 


\section{Przypadek szczególny. Kolekcja lub kolekcje w służbie wyjątkowej osoby}

Niniejsza część artykułu prezentuje szczególną postać kolekcji średniowiecznej - kolekcję osobistą. Kolekcje wspólnotowe, tworzone przez zakony, diecezje, królestwa, pełniły funkcję w szerokim kontekście społecznym i wyrażały treści i wartości właściwe dla społeczności. Ich trwanie i wzrost przekraczał życie jednego, a nawet wielu pokoleń. Kolekcja indywidualna wyrażała preferencje, decyzje i wartości jednej osoby, jej formację, osobowość oraz działanie. Jej budowanie kończyło się z chwilą śmierci osoby. Kolekcje takie mają więc swój szczególny charakter, różny od charakteru zbiorów społecznościowych. Należy więc się im przyjrzeć i podjąć próbę analizy.

$$
*^{*} *
$$

W kodeksie Glossa super Leviticum na karcie 1v (Kraków, Biblioteka Kapitulna, 66) z początku XIII wieku spisany jest prywatny księgozbiór. Składają się nań 32 woluminy, które zawierają 41 dzieł ${ }^{46}$. Są to teksty z zakresu biblistyki, dzieła patrystyczne, prace historyczne, literackie teksty autorów francuskich i angielskich. Najprawdopodobniej mamy do czynienia z prywatną biblioteką człowieka, który zdobył wykształcenie na zachodnioeuropejskich uniwersytetach. Księgozbiór ten stanowił warsztat pracy intelektualisty, a tym samym odzwierciedlał preferencje umysłowe i duchowe właściciela oraz wyrażał kierunki jego poszukiwań umysłowych. Charakteryzuje się on uniwersalnością horyzontów i zainteresowań intelektualnych osoby oraz korzystaniem z dużej liczby źródeł teologicznych.

Wybitną osobistością świata polityki i kultury był śląski Piast, książę Ludwik brzeski. W swoim testamencie z roku 1360 zadysponował on swoimi zbiorami ${ }^{47}$. Testament ten jest znakomitym źródłem do poznania

46 Z. Budkowa, Księgozbiór polskiego uczonego z XII/XIII wieku, „Studia Źródłoznawcze” 1 (1957), s. 109-118.

47 Verschiedene letztwillige Bestimmungen Herzogs Ludwig: Brieger Stadtbuch, I, f. 37. Urkunden der Stadt Brieg, [w:] Codex diplomaticus Silesiae, t. 9, Urkunden der Stadt Brieg, Hg. C. Grünhagen, 
kolekcjonerskich pasji księcia. Opisany w testamencie zbiór jest kolekcją kolekcji. Pierwszą więc kolekcją tego zbioru był księgozbiór, w którego składzie znalazła się Kronika polsko-ślaska z 1359 roku, Summa Theologica św. Tomasza z Akwinu, dzieła Boecjusza, Seneki, kodeks z legendą obrazową o św. Jadwidze, dzieła prawnicze. Drugą kolekcją był zbiór przedmiotów liturgicznych, wśród których znajdował się komplet szat kapłańskich, casula de marmoctio, czyli purpurowy ornat zdobiony złotą nicią i szlachetnymi kamieniami, kielich, kilka ostensoriów, lichtarz, naczynie do wody, złote kadzielnice, skrzynka relikwiarzowa, krzyż relikwiarzowy. Testament ten wykazuje również tabulas oraz ymagines de ebore. Chodzi tu najprawdopodobniej o obrazy tablicowe oraz o drobne reliefy i figurki z kości słoniowej.

Późniejsze spisy przedmiotów zostały zamieszczone w przywileju z roku 1386 oraz w drugim testamencie z roku $1396^{48}$. Najważniejszą wykazaną kolekcją tych spisów jest księgozbiór. Dokumenty powyższe ukazują jednak szerszy zakres zbieractwa. Alicja Karłowska-Kamzowa twierdzi, że można wszystkie pozostałe przedmioty podzielić na trzy grupy. Do pierwszej grupy należą instrumenty sprawowania liturgii - kielichy, ostensoria, naczynia określane ogólnie jako vasa sacra oraz insygnia dziekana kolegiaty i rektora szkoły. Do drugiej grupy należał zbiór relikwii w relikwiarzach. Jako nazwy relikwiarzy wymieniane są ladula, capsa, scrinium. Spis wykazuje istnienie małego i wielkiego krzyża relikwiarzowego, nieokreślonej formy relikwiarza św. Elżbiety, księgi w oprawach z małymi relikwiarzami oraz relikwiarzy transparentnych. Do trzeciej grupy wchodziły jaspisy, perły i inne kamienie szlachetne, a także gemmy i kryształy.

Właściwie w przypadku zbioru wszystkich pozostałych przedmiotów z wyjątkiem księgozbioru możemy mówić o wyrażaniu, obrazowaniu i wspomaganiu życia religijnego i duchowości księcia i jego dworu. Służy on bowiem liturgii w kaplicy książęcej (przedmioty liturgiczne),

\footnotetext{
s. 246-247; A. Karłowska-Kamzowa, Fundacje artystyczne księcia Ludwika brzeskiego: studia nad rozwojem świadomości historycznej na Śląsku XIV-XVIII wieku, Opole-Wrocław 1970, s. 47-51.

48 Verschiedene letztwillige Bestimmungen Herzogs Ludwig..., dz. cyt., s. 251-255 [przywilej]; Verschiedene letzwillige Bestimmungen Herzogs Ludwig..., dz. cyt., s. 254-255 [2 testament]; A. Karłowska-Kamzowa, Fundacje artystyczne księcia Ludwika brzeskiego..., dz.cyt., s. 72.
} 
unaocznia związek z Kościołem zbawionych i kult świętych (relikwie) oraz nadaje życiu religijnemu i dworskiemu blask (perły, kamienie, gemmy).

Odczytanie znaczenia kolekcji osobistej w wiekach średnich wbrew pozorom nie jest łatwe. O ile kolekcje publiczne - skarbce, księgozbiory i zbiory relikwii przeznaczone były w większym lub mniejszym stopniu do oglądu i użytku wspólnotowego, przy założeniu określonego czasu korzystania z nich, o tyle kolekcja osobista jest przeznaczona tylko dla swego twórcy i posiadacza. Takie stwierdzenie rodzi wiele pytań. Czy kolekcja osobista jest wyrazem jedynie indywidualnych preferencji aksjologicznych, czy może powszechnie panujących dążeń umysłowych i duchowych epoki, właściwych ludziom elity władzy i kultury? Czy kolekcja związana jest ze sprawowanym urzędem, rolą społeczną, czy może wyraża prywatne upodobania? Czy jest komunikatem kierowanym jedynie do posiadacza, czy może niesie orędzie, które twórca i właściciel chciał skierować do współczesnych mu ludzi? Odpowiedź na te pytania wymaga jeszcze wiele wytrwałego wysiłku badawczego.

\section{Kolekcja średnioweczna - pośrednik między niewidzialnym a widzialnym}

Czym była średniowieczna kolekcja, której podstawowe rodzaje poddano analizie w niniejszym tekście? Jaką rolę pełniła w kulturze epoki, bez względu na rodzaj przedmiotów, jakie w sobie mieściła? Pytania te rodzą się, gdy pochylamy się nad zbiorami przedmiotów - pozostających poza sferą codzienności, cennych, chronionych, otoczonych pietyzmem i kultem. Wydaje się, że dotychczas najbardziej trafną teorię wyjaśniającą istnienie i funkcjonowanie kolekcji sformułował Krzysztof Pomian. Ten filozof, antropolog i badacz kultury zadał pytanie o to, co dzieje się, gdy przedmioty wyłączone z codziennego użytku i obiegu ekonomicznego, a włączone do sfery nadprzyrodzonej i poświęcone bogom, są oglądane przez śmiertelników ${ }^{49}$. Odpowiedzią było odkrycie, że tego rodzaju przed-

${ }^{49}$ K. Pomian, Zbieracze i osobliwości: Paryż-Wenecja XVI-XVIII wieku, przeł. A. Pieńkoś, Warszawa 1990, s. 33. 
mioty pośredniczą w komunikacji między śmiertelnymi a nieśmiertelny$\mathrm{mi}^{50}$. Zbiór poświęconych przedmiotów pozostający w sferze profanum pośredniczy w komunikacji między sacrum a profanum. Co więcej, możliwa jest tutaj więź międzyosobowa, ponieważ przedmioty mogą reprezentować osoby zwyczajnie niewidzialne, bytujące z drugiej strony granicy dzielącej sacrum i profanum ${ }^{51}$. Kolekcja jednak nie jest jedynym środkiem mającym łączyć dwa światy - widzialny i niewidzialny ${ }^{52}$.

Koncepcja kolekcji jako łącznika między widzialnym i niewidzialnym poprzedzona została analizami wielu kolekcji pojawiających się w różnych czasach i kulturach i wydaje się spójna, logiczna i trafna. Jej mankamentem jest jednak owo ustanowienie dystansu między rzeczywistością i osobą widzialną oraz rzeczywistością i osobą niewidzialną. Wątpliwości budzi dychotomiczny podział rzeczywistości na sacrum i profanum, który wcale nie musi być tożsamy z rozróżnieniem na świat przyrodzony i nadprzyrodzony oraz na rzeczywistość duchową i materialną. Chrześcijaństwo w swoich źródłach, przede wszystkim biblijnych, a także patrystycznych, nie zna dychotomii profaniczno-sakralnej. Zbyt mocną wydaje się linia graniczna między obiema strefami i konieczność posiadania zdolności do jej przekraczania. Kultura średniowieczna charakteryzowała się przenikaniem obu rzeczywistości.

Chrześcijaństwo średniowieczne, na co wskazują źródła pisane oraz dzieła sztuki, odczytywane w warstwie ikonologicznej, koncentruje się wokół tajemnic wcielenia i odkupienia. Oba wielkie dramaty rozgrywają się w sytuacji i kontekście ludzkiej historii, w której splata się świat ducha i materii, świat ludzkiej kultury i Bożego objawienia. Kultura wieków średnich charakteryzuje sie dążeniem do unaocznienia, uczynienia widzialnym tajemnicy. Zwrócił na to uwagę Georges Duby, uwypuklając rolę przechowywanych relikwii, liturgii i muzyki, a także malarstwa i rzeźby $^{53}$. Roland Pecht przeanalizował rzeczywistość widzialności sakramentów, zwracając uwagę na coraz bardziej powszechne od XIII wieku dąże-

50 K. Pomian, Zbieracze i osobliwości..., dz.cyt., s. 33.

51 K. Pomian, Zbieracze i osobliwości..., dz.cyt., s. 33.

52 K. Pomian, Zbieracze i osobliwości..., dz. cyt., s. 37.

53 G. Duby, Les Temps des cathedrales: l'art et la société 980-1420, Paris 1977, s. 95-162. 
nie do oglądania podnoszonej czy wystawianej konsekrowanej Hostii ${ }^{54}$. Otto von Simson, poszukując genezy i znaczenia gotyckiej katedry, zwrócił uwagę na dwie cechy tej budowli. Pierwszą byłyby matematyczne proporcje, drugą - obecność światła w przestrzeni. Doskonałe proporcje miały ujawniać Boga jako architekta wszechświata, a światło wypełniające wnętrze miało być uobecnieniem Boskiej Światłości ${ }^{55}$.

Analizy i interpretacje trzech przytoczonych autorów świadczą o tym, że człowiek średniowieczny bardzo intensywnie przeżywał pojawienie się, zmaterializowanie, wcielenie nadprzyrodzoności pośród codzienności, historii, życia społecznego oraz życia wspólnoty kościelnej.

Wydaje się więc, że kolekcja, zbiór przedmiotów wyłączonych z użycia potocznego i społecznego obiegu i poświęconych użytkowi religijnemu i intelektualnemu, charakteryzowała się zdolnością nie tyle pośredniczenia, ile raczej uobecniania „tu i teraz” tego, co nadprzyrodzone, czyli stawania pośrodku historii, pośrodku życia społeczności świeckiej i wspólnoty kościelnej, pośrodku kultury. Istotny jest historyczny moment, w którym kolekcja powstaje, i cały wieloaspektowy oraz wielowymiarowy kontekst jej pojawienia się. Kolekcja jako taka powinna być raczej zdefiniowana jako uobecnienie lub epifania ${ }^{56}$. Właściwe wydaje się również określenie tego szczególnego i wyjątkowego dzieła jako znaku czasu ${ }^{57}$. Epifania uwypukla ujawnienie się w pełnym blasku i naoczności tego, co jest nadprzyrodzone. Znak czasu nadaje kolekcji charakter nowego wydarzenia historycznego, niosącego orędzie na czas, w którym zaistniało, i stającego się wezwaniem do podjęcia działania. Jednakże epifania to nie jest ujawnienie się bezosobowego sacrum, lecz objawienie się osobowego Boga. Czy więc zbiór przedmiotów może być narzędziem takiego objawienia? Znak czasu to wydarzenie, lecz aby mogło zostać zidentyfikowane i odczytywane, musi być powszechnie dostępne. Wiadomo z powyższych analiz,

54 R. Pecht, Le croire et le voire: l'art des cathédrales XIIe-XIVe siècle, Paris 1999, s. 97-145.

55 O. von Simpson, Katedra gotycka: jej narodziny i znaczenie, przeł. A. Palińska, Warszawa 1989, s. 46-92.

56 J. Szlaga, Epifania, [w:] Encyklopedia katolicka, t. 4, red. R. Łukaszyk, L. Bieńkowski, F. Gryglewicz, Lublin 1983, kol. 1020-1021.

57 R. Fisichella, Signos de los tiempos, [w:] Diccionario de teologia fundamental, dir. por R. Latourelle, R. Fisichella, Madrid 1992, s. 1360-1368. 
że dostęp do kolekcji był zarezerwowany do ściśle określonych kategorii osób. Czy więc kolekcja mogłaby pełnić rolę takiego wydarzenia i nośnika znaczeń? W obecnym tekście nie sposób zadowalająco odpowiedzieć na te dwa pytania. Wynika z tego, że te cząstkowe definicje - epifania i znak czasu - powinny być przedmiotem osobnych badań, uściśleń i dopracowań. Na czas obecny niech pozostaną hipotezami roboczymi, a sformułowane pytania niech inspirują do przemyśleń.

\section{Zakończenie}

Średniowieczne kolekcje okazują się szczególnymi tworami kultury przyjmującymi specyficzne funkcje oraz mającymi zdolność przenoszenia znaczeń i komunikatów. Skarbce - liturgiczne i regalne - komunikowały głębokie treści liturgii oraz konsekrowaną godność osoby koronowanej. Biblioteki określały universum intelektualne i duchowe. Zbiory relikwii unaoczniały rzeczywistość communicatio sanctorum. Do zbadania pozostaje szczególna rola i znaczenie wielu średniowiecznych kolekcji - skarbców, bibliotek i zbiorów relikwii w ich kontekście kulturowym, religijnym i politycznym. Nade wszystko pojawia sie zadanie znalezienia odpowiedzi na pytanie: czy kolekcja może być zdefiniowana jako epifania, czy jako znak czasu. 


\title{
Summary
}

\author{
Kolekcje chrześcijanstwa: próba odczytania znaczenia \\ na podstawie wielkich zbiorów średniowiecza
}

Niniejszy tekst rozważa znaczenie i treść trzech typów średniowiecznych kolekcji kościelnych - skarbców, bibliotek i zbiorów relikwii. Przypadkiem szczególnym są prywatne zbiory osób należących do elit. Jednakże średniowieczne kolekcje chrześcijańskie poprzedzone były poprzez pogańskie zwyczaje gromadzenia przedmiotów wyłączonych z codziennego użytku w grobach. Przytoczono jako przykłady grób Childeryka w Tournai i grób Raedwalda w Sooton Hoo. Skarbiec zawierał przedmioty służące sprawowaniu liturgii oraz regalia - symbole władzy królewskiej. Miały one symbolizować jedność regnum i sacerdotium, głównych rzeczywistości społecznych średniowiecza. Biblioteka kolekcja książek stanowiła zbiór narzędzi do nauczania i prowadzenia badań naukowych. Zbiór relikwii był obrazem nadprzyrodzonej wspólnoty świętych - osób zbawionych oraz uobecniał jej chwałę przed oczami wiernych. Kolekcja różnorodnych przedmiotów książek, relikwii, klejnotów, przedmiotów liturgicznych - należąca do uczonego albo do osoby sprawującej władzę spełniała wyjątkową rolę i niosła szczególne znaczenie. Ujawniała ona intelektualne preferencje tej osoby oraz religijne i duchowe wartości, jakimi ona żyła. Znaczenie kolekcji zostało opracowane przez Krzysztofa Pomiana. Twierdził on, że kolekcja jest pośrednikiem między sferą widzialną i niewidzialną, między rzeczywistością śmiertelnych i rzeczywistością nieśmiertelnych. Jednakże koncepcja Krzysztofa Pomiana wydaje się niewystarczająca wobec zawartości, ról i znaczeń wyżej przeanalizowanych kolekcji średniowiecznych. Możliwe jest jednakże zastosowanie do opisu i interpretacji kolekcji pojęć epifanii i znaku czasu.

Słowa kluczowe: kolekcja, skarbiec, biblioteka, księgozbiór, relikwie, relikwiarz, widzialne, niewidzialne

\section{Collections of Christianity: Interpretation of Meaning on the Base of Grand Collection of the Middle Ages}

This paper considers the importance and the meaning of three types of medieval collections - treasuries, libraries and relics. The particular case were the private collections of objects, belonging to the important persons. However medieval christian collections has been preceded by the collection of object collected in the tombs of rulers. We find the famous examples in the tomb of Readwald in Sooton Hoo and in the tomb of Childericus in Tournai. The christianity assumed idea of collection and collectioning in his own culture and created three types of collections - treasury, library and relics. Treasury holds the objects in service of liturgy and the regalia- 
objects of coronation. The principal meaning of these collection was to reveal the regnum and sacerdotium, principal realities of medieval Church and state.

The libraries, the collections of books was the instruments of teaching and research, but it created some image of intellectual universum. The collections of relics revealed the community of saints and presented its splendour before the eyes of faithfulls.

The particular role and special meaning had the collections of objects - books, jewels, relics, liturgical object belonging to the scholars or to the rulers. In fact this collection revealed the intellectual preferences and spiritual, religious values of these persons.

The meaning of collection has been elaborated by Krzysztof Pomian. He asserts, that collection is the mediation between visible and invisible, between mortals and immortals. However, the concept of Krzysztof Pomian seems to be insuffisante towards content, function and meaning of ecclesiastical collection. So it is possible to applicate the concepts of epiphany or sign of time to describe et interpret this type of collection.

Keywords: collection, treasury, library, book collection, relics, reliquiary, visible, invisible

\section{Bibliografia}

Actatesauri Regni Poloniae saeculi XVII (Kraków, Biblioteka Czartoryskich, rkps III 1080). Beowulf: revised edition, edited with an introduction, notes and new prose translation by M. Swanton, Manchester-New York 1997.

Bielak W., Księgozbiór panien Norbertanek w Imbramowicach, „Archiwa, Biblioteki i Muzea Kościelne" 95 (2011), s. 5-10.

Budkowa Z., Księgozbiór polskiego uczonego z XII/XIII wieku, „Studia Źródłoznawcze” 1 (1957), s. 109-118.

Castelfranchi Vegas L., Arte ottoniana interno al anno mille, Milano 2002.

Croix Bouton J. de la, Stephan Harding, [w:] Lexikon des Mittelalters, t. 18, StuttgartWeimar 1999, kol. 119-120.

De Montesquiou-Ferenza B., Gaborit-Chopin D., Le trésor de Saint-Denis: documents divers, Paris 1977.

Długosz J., Liber beneficiorum dioecesis Cracoviensis, t. 1, Cracoviae 1863.

Duby G., Les Temps des cathedrales: l'art et la société 980-1420, Paris 1977.

Fedorowicz S., Średniowiecznelekcjonarze w zbiorach wawelskich, „Archiwa, Biblioteki i Muzea Kościelne" 89 (2008), s. 195-224.

Filitz H., Die Schatzkammer in Wien: Symbole abendländischen Kaisertums, Wien 1986.

Fisichella R., Signos de los tiempos, [w:] Diccionario de teologia fundamental, dir. por R. Latourelle, R. Fisichella, Madrid 1992, s. 1360-1368.

Hamryszczak A., Bibliografia zawartości pótrocznika „Archiwa Bibliotekii Muzea Kościelne”, t. 1-100, „Archiwa, Biblioteki i Muzea Kościelne” 101 (2014), s. 5-91.

Jażdżewski K. K., Lubiąz: losy i kultura umysłowa śląskiego opactwa cystersów (11631642), Wrocław 1993. 
Karłowska-Kamzowa A., Fundacje artystyczne księcia Ludwika brzeskiego: studia nad rozwojem świadomości historycznej na Ślasku XIV-XVIII wieku, Opole-Wrocław 1970.

Kopeć-Zaborniak U., Dzieje księgozbiorów średniowiecznych bibliotek benedyktyńskich, „Archiwa, Biblioteki i Muzea Kościelne” 90 (2008), s. 79-89.

Kopera F., Dzieje skarbca koronnego, czyli insygniów i klejnotów koronnych polskich, Kraków 1904.

Lannert Ch., Die Reichskleinodien:Bedeutung, Symbolikund Gebrauch der Herschaftszeichen des Alten Reiches, München 2013.

Lener A., Reliquien In Kunst und Kult zwischen Antike Und Aufklärung, Darmstadt 1995.

Le trésor de Saint-Denis : catalogue de l'exposition au musée du Louvre du 12 mars au 17 juin 1991, Paris 1991.

Mencfel M., Skarby natury i sztuki: prywatne gabinety osobliwości, kolekcje sztuki i naturaliów na Śląsku w wiekach XVII i XVIII, Warszawa 2010.

Myśliński M., Klejnoty Rzeczypospolitej: zawartość skarbca koronnego na Wawelu w świetle jego inwentarzy z lat 1475-1792, Warszawa 2007.

Palazzo E., Liturgie et Société au Moyen Âge, Paris 2000.

Pomian K., Zbieracze i osobliwości: Paryż-Wenecja: XVI-XVIII wiek, przeł. A. Pieńkoś, Warszawa 1990.

Pecht R., Le croire et le voire: l'art des cathédrales XIIe-XIVe siècle, Paris 1999.

Plezia M., Księgozbiór katedry krakowskiej wedle inwentarza z roku 1110, [w:] Silva Rerum, Kraków 1981, s. 16-29.

Rybandt S., Średniowieczne opactwo cystersów w Rudach, Wrocław 1971.

Ryszkiewicz A., Zbieracze i obrazy, wyd. 1, Warszawa 1972.

Ryszkiewicz A., Kolekcjonerzy i miłośnicy, wyd. 2, Warszawa 1981.

Sawicki W., Rytuał sakry - koronacji jako źródło prawa i ustroju państw średniowiecznej Europy, „Archiwa, Biblioteki i Muzea Kościelne” 24 (1972), s. 279-293.

Skarby Rzeczypospolitej: z dziejów kolekcjonerstwa sztuki w Polsce od XIII do końca XVIII wieku, red. D. Folga-Januszewska, A. Rottermund, Olszanica 2003.

Schaller H. M., Die wiener Reichskrone - enstanden unter König Konrad III, [w:] Die Reichskleinodien. Herschaftszeichen des Heiligen Römischen Reiches, Hg. K. H. Ruess, Göppingen 1997, s. 58-105.

Simpson O. von, Katedra gotycka: jej narodziny i znaczenie, przeł. A. Palińska, Warszawa 1989.

Starnawska M., Krucjata i Ziemia Święta $w$ duchowości zakonów krzyżowych w Polsce średniowiecznej, „Saeculum Christianum” 3 (1996) nr 1, s. 167-179.

Starnawska M., Świętych życie po życiu: relikwie w kulturze religijnej na ziemiach polskich w średniowieczu, Warszawa 2008.

Stolarczyk T., Książka i biblioteka w życiu średniowiecznych i staropolskich konwentów dominikańskich na przykładzie klasztorów środkowopolskich „Archiwa Biblioteki i Muzea Kościelne" R. 100 (2013), s. 341-354.

Szlaga J., Epifania, [w:] Encyklopedia katolicka, t. 4, red. R. Łukaszyk, L. Bieńkowski, F. Gryglewicz, Lublin 1983, kol. 1020-1021. 
Trnek H., Die Insignien des Heiligen Römischen Reiches, [w:] Die Reichskleinodien. Herschaftszeichen des Heiligen Römischen Reiches, Hg. K. H. Ruess, Göppingen 1997, s. 10-29. Verger J., L'exégèse de l'Université, [w:] Le Moyen Âge et la Bible, sous la direction de P. Riché et G. Lobrichon, Paris 1984.

Verschiedene letztwillige Bestimmungen Herzogs Ludwig: Brieger Stadtbuch, I, f. 37. Urkunden der Stadt Brieg [w:] Codex diplomaticus Silesiae, Hg. C. Grünhagen, t. 9, s. 246-247.

Vetulani A., Krakowska biblioteka katedralna w świetle swego inwentarza z roku 1110, „Slavia Antiqua”, R. IV (1953/54), s. 163-192.

Waźbiński Z., Muzea i zbiory artystyczne epoki nowożytnej: wiek XVi XVI,t. 1, Toruń 2006.

Załuska Y., L'enluminure et le scriptorium de Cîteuax au XIIe siècle, Cîteaux 1989.

Załuska Y., Manuscrits enluminés de Dijon, Paris 1991.

Zawadzka K., Biblioteka klasztoru dominikanów we Wrocławiu (1226-1810), [w:] Studia nad dziejami dominikanów w Polsce 1222-1972, t. 2, red. J. Kłoczowski, Warszawa 1975, s. 307-308.

Żygulski jun. Z., Muzea na świecie: wstęp do muzealnictwa, Warszawa 1982. 